\title{
Inhalt, Vol. 5, No. 5, 1982
}

\section{Contents}

Impressum 215

Rojo, J. und Glöckner, W. M., Köln

Klinik der Haarzell-Leukämie und ihre Beeinflussung

durch Splenektomie 216

Mitrou, P. S.; Fischer, M.; Bergmann, L. und ; Hübner, K. , Frankfurt

Sequentielle Chemotherapie maligner Non-Hodgkin-

Lymphome (NHL) von hohem Malignitätsgrad im Sta

dium III und IV 222

Metzger, U.; Schneider, K. und Largiadèr, F., Zurich Adjuvante Therapie des Kolon- und

Rektumkarzinoms

- $\quad$ Übersicht über den heutigen Stand - 228

Meerpohl, H. G.; Pfleiderer, A.; Kleine, W. und

Teufel, G., Freiburg

Ovarial-Karzinome der Stadien III-IV: Ergebnisse mit

dem CAP-Schema bei nicht vorbehandelten Patientinnen 238

Schumacher, C; Hiller, E.; Scherer, U. und

Wilmanns, W. , München

Intrakranieller Befall bei Lymphogranulomatose

Sonderbände 248

Bartsch, H. H.; Blossey, H. Ch. und Nagel, G. A.,

Göttingen

Mitomycin C und hochdosiertes Medroxyprogesteron-

acetat in der Therapie des metastasierenden Mamma-

karzinoms

- $\quad$ Ergebnisse einer Phase-II-Studie der AIO - 249

Hinweise für Autoren 257

Buchbesprechungen 258

Onkologie-Mitteilungen

Imprint215

Rojo, J. and Glöckner, W. M., Köln

Hairy Cell Leukaemia - Clinical Features and Effect of

Splenectomy 216

Mitrou, P. S.; Fischer, M.; Bergmann, L. and

Hübner, K., Frankfurt

Sequential Combination Chemotherapy of High-Grade

Malignant (Non-Hodgkins') Lymphomas Stage III

and IV 222 
Metzger, U.; Schneider, K. and Largiadèr, F., Zurich

Adjuvant Therapy of Colorectal Cancer

- An Overview - 228

Meerpohl, H. G.; Pfleiderer, A.; Kleine, W. and

Teufel, G., Freiburg

Chemotherapy for Stage III-IV Ovarian Cancer: The

CAP-Regimen in Previously Untreated Patients 238

Schumacher, C; Hiller, E.; Scherer, U. and

Wilmanns, W., München

Intracerebral Manifestations of Hodgkin's Disease .... 242

Special Editions 248

Bartsch, H. H.; Blossey, H. Ch. and Nagel, G. A., Göttingen

Mitomycin $\mathrm{C}$ and High-Dose Medroxyprogesterone Ace

tate in the Treatment of Metastatic Breast Cancer

-ResultsofaPhase-II-StudyoftheAIO- 249

Instructions for Authors 257

Book Reviews 258

Oncology Communications 259

Bibliographischer Hinweis: Inhaltsverzeichnisse dieser Zeitschrift erscheinen regelmäßig in current contents ${ }^{\circledR}$ sowie in anderen bibliographischen Diensten. 